\title{
Longest continually erupting large igneous province driven by plume- ridge interaction
}

\author{
Q. JIANG ${ }^{1}$, F. JOURDAN ${ }^{1 *}$, H.K.H. OLIEROOK ${ }^{1,2}$, R.E.
} MERLE $^{3}$, M.F. COFFIN ${ }^{4,5}$, J.M. WHITTAKER ${ }^{4}$

${ }^{1}$ John de Laeter Centre and School of Earth and Planetary Sciences, Curtin University, Perth, WA 6845, Australia

${ }^{2}$ Centre for Exploration Targeting - Curtin Node, School of Earth and Planetary Sciences, Curtin University, Perth, WA 6845, Australia

${ }^{3}$ Swedish Museum of Natural History, S-104 05 Stockholm, Sweden

${ }^{4}$ Institute for Marine and Antarctic Studies, University of Tasmania, Hobart, Tasmania 7001, Australia

${ }^{5}$ School of Earth and Climate Sciences, University of Maine, Orono, Maine 04469-5790, USA and Woods Hole Oceanographic Institution, Woods Hole, Massachusetts 02543, USA

\section{*presenting author}

Large igneous provinces are usually emplaced in one short pulse of $\sim 1-5$ million years, or several punctuated, $\sim 1-5$ million year pulses. Here, our new plagioclase ${ }^{40} \mathrm{Ar} /{ }^{39} \mathrm{Ar}$ plateau ages for the main construct of the Kerguelen large igneous province - the Southern and Central Kerguelen Plateau, Elan Bank and Broken Ridge - show continuous volcanic activity from range from $122.2 \pm 2.6$ Ma to $89.9 \pm$ $1.0 \mathrm{Ma}$ and more specifically from $\sim 122$ to $\sim 90 \mathrm{Ma}$ for the Southern Kerguelen Plateau, from $\sim 111$ to $\sim 106$ Ma for Elan Bank, from $\sim 109$ to $\sim 93 \mathrm{Ma}$ for the Central Kerguelen Plateau, and from $\sim 99$ to $\sim 98 \mathrm{Ma}$ for Broken Ridge, i.e. a long lifespan of $>32$ million years. This suggests that the Kerguelen large igneous province records a previously undocumented emplacement tempo for large igneous provinces. Distinct from short-lived and multiple-pulsed large igneous provinces, we propose that Kerguelen is a new type of large igneous province that formed due to long-term plume-ridge interaction and jump(s) of the spreading ridge towards the plume. Such a process allows for transport of magma products away from the eruption centre, thus creating space for the magma to continuously rise, and results in longlived, continuous magmatic activity. 